\title{
Important blood pressure changes in clinical practice: narrative literature review
}

\author{
Alterações importantes na pressão arterial na prática clínica: \\ revisão narrativa de literatura
}

\author{
Maria Cristina PEDRAZINI' ID 0000-0002-7649-6626 \\ Luciane Francischini Gottschall ODONE² iD 0000-0002-8955-8363 \\ Mônica Feresini GROPPO3 iD 0000-0002-9434-9048 \\ Francisco Carlos GROPPO' ID 0000-0002-8513-773X
}

\begin{abstract}
The aim of this study was to emphasize the importance of monitoring vital signs, especially blood pressure, during dental care. Through a narrative review, the changes in blood pressure that may occur during outpatient procedures and the measures to be taken were discussed. The available literature was consulted in databases (PubMed, Scielo, Web of Science and Google Scholar), complemented by the analysis of the bibliographic references included and updated until April 2021. The keywords were used: "Anamnesis", "Arterial Pressure", "Arterial Hypertension", "Hypertensive Crisis", "Risk factors", "Stroke", "Subclavian Theft Syndrome" and "Atherosclerosis". It was concluded that care should be applied to all patients, but mainly to those over 50, hypertensive or not, with hypercholesterolemia, diabetes, anxious and fearful. All vital signs must be monitored, including the pain score. The situations of anxiety, pain and fear are triggers for changes in blood pressure even in normotensive patients as in controlled hypertensive patients. The blood pressure measurement, in the first consultation, must be performed in both arms and repeated annually or whenever there is a change in the patient's health status. In all other consultations, blood pressure control, as well as the assessment of all vital signs, must be performed before, during, after the procedure and before discharge. In the face of any major change, it is necessary to assess the risk/benefit ratio of the continuity of the procedure, so that risks to patients are avoided or minimized, as well as for the necessary referrals to be made.
\end{abstract}

Indexing terms: Arterial pressure. Hypertension. Risk factors.

\section{RESUMO}

O objetivo deste trabalho foi enfatizar a importância da monitorização dos sinais vitais, particularmente da pressão arterial durante o atendimento odontológico. Por meio de uma revisão narrativa foram discutidas as alterações pressóricas que podem ocorrer durante

$\boldsymbol{\nabla} \mathbf{\nabla} \boldsymbol{\nabla}$

1 Universidade Estadual de Campinas - UNICAMP, Faculdade de Odontologia de Piracicaba, Departamento de Biociência. Av. Limeira, 901 , Areião, 13414-903, Piracicaba, SP, Brasil. Correspondence to: MC PEDRAZINI. E-mail: <mcpequipe@gmail.com>.

2 Hospital dos Fornecedores de Cana de Piracicaba - HFCP, Departamento de Cardiologia/ Ecografia. Piracicaba, SP, Brasil.

${ }^{3}$ Centro Estadual de Educação Tecnológica Paula Souza. Piracicaba, SP, Brasil.

$\checkmark v \nabla$

How to cite this article

Pedrazini MC, Odone LFG, Groppo MF, Groppo FC. Important blood pressure changes in clinical practice: narrative literature review. RGO, Rev Gaúch Odontol. 2022;70:e20220001. http://dx.doi.org/10.1590/1981-86372022000120210054 
procedimentos ambulatoriais e as medidas a serem tomadas. A literatura disponível foi consultada em bancos de dados (PubMed, Scielo, Web of Science e Google Scholar), complementada analisando as referências bibliográficas incluídas e atualizada até Abril de 2021. Foram usadas as palavras-chave: Anamnese, Pressão Arterial, Hipertensão Arterial, Crise Hipertensiva, Fatores de Risco, Acidente Vascular Cerebral, Síndrome do Roubo da Subclávia e Aterosclerose. Foi concluído que os cuidados devem ser aplicados em todos os pacientes mas em especial naqueles com idades superiores a 50 anos, hipertensos ou não, com hipercolesterolemia, diabetes, ansiosos e medrosos. Todos os sinais vitais devem ser monitorados, dentre eles, o score de dor. As situações de ansiedade, dor e medo são gatilhos para alterações pressóricas tanto em pacientes normotensos como nos hipertensos controlados. A aferição da pressão arterial, já na primeira consulta, deve ser realizada em ambos os braços e repetida anualmente ou sempre que houver modificação no quadro de saúde do paciente. Em todas as demais consultas, o controle pressórico como também a avaliação de todos os sinais vitais, deve ser no pré-, trans-, pós-procedimento e antes da alta. Diante de qualquer alteração importante, a relação risco/benefício da continuidade do procedimento precisa ser avaliada, para que seja evitado ou minimizado os riscos aos pacientes bem como para realizar os encaminhamentos necessários.

Termos de indexação: Pressão arterial. Hipertensão. Fatores de risco.

\section{INTRODUCTION}

With the growth in life expectancy worldwide, the presence of elderly people with associated comorbidities has been increasing in medical and dental offices. Especially in Dentistry, associated comorbidities must be observed with caution. The vast majority of dental procedures involve local anesthesia, anxiety and fear of treatment, factors that can decompensated the patient who is awake in an outpatient care, often without any sedation. Candidate patients for oral rehabilitation, involving invasive surgical procedures such as grafting and installation of osseointegrated implants, usually have ages over 50 years and comorbidities such as diabetes, heart disease, cholesterol alteration, atherosclerosis and especially systemic arterial hypertension (SAH).

The SAH is characterized by constant systolic and diastolic pressure values, at several times during wakefulness, $\geq 140 \times 90 \mathrm{mmHg}[1,2]$.

In a survey carried out in Brazilian capitals among people over 18 years of age, SAH was more common in women, increasing the proportion with increasing age. To the 65 years old, about $61 \%$ of the population already had SAH [3].

With advanced age and arterial aging, atheromatous plaques and calcifications adhere to the arterial walls, decreasing their lumen. The reduction of collagen and elastin, mainly in the walls of the aorta, impair the compensatory elasticity when a different pressure condition, called isolated systolic hypertension (ISH), sets in [2]. Another important manifestation that affects poorly controlled hypertensive patients and even some normotensive ones, is the hypertensive crisis $(\mathrm{HC})$, which can occur during outpatient procedures. Given this information, the importance of blood pressure control, in all procedures and in more than one moment, must be observed in many patients [4].

For smokers, diabetics, hypertensive patients or those over 50 years of age, it is indicated that, in the first appointment and every 12 months, blood pressure (BP) must be measured in both arms and, in the face of important pressure differences, the patient should be referred to a doctor for investigation [5].

The Brazilian Society of Cardiology recommends that BP should be checked in every health assessment, by doctors of different specialties and other health professionals, all properly trained [2].

Dental surgeons, as well as other health professionals, intervene in patients on an outpatient procedures, applying drugs and local anesthetics, generating anxiety and fear. The aim of this study is to emphasize the importance of monitoring vital signs, particularly blood pressure, during these visits and in the face of any changes, making the most assertive decisions, as well as making the necessary referrals.

\section{METHODS}

This narrative review included searches in the PubMed, Web of Science, Scielo and Google Scholar databases using the keywords "Anamnesis", "Arterial Pressure", "Arterial Hypertension", "Hypertensive Crisis", "Risk Factors", " 
Stroke ", "Subclavian Theft Syndrome" and "Atherosclerosis". The electronic search was complemented by the manual search of reference lists of the included articles. The survey was updated in April 2021.

\section{DISCUSSION}

\section{Systemic arterial hypertension}

Several guidelines can be followed on when to start treating hypertensive patients. The last american guideline of 2017, considers a normotensive patient when BP values are $<120 \times 80 \mathrm{mmHg}$. Therapeutic measures should be evaluated when the values are constant $\geq 130 \times 80 \mathrm{mmHg}$ being considered stage I of hypertension up to values of $139 \times 89 \mathrm{mmHg}$ [6] (table 1). However, for european society in its last guideline of 2018, a patient will be normotensive when BP is $\leq 139 \times 89 \mathrm{mmHg}$. In the european guideline, stage I of hypertension occurs when BP is at constant levels between 140x90 and 159x99 $\mathrm{mmHg}$, this guideline being less conservative [1] (table 2).

Table 1. Categories of BP in adults.

\begin{tabular}{|c|c|c|c|}
\hline BP Category & SBP & & DBP \\
\hline Normal & $<120 \mathrm{~mm} \mathrm{Hg}$ & and & $<80 \mathrm{~mm} \mathrm{Hg}$ \\
\hline Elevated & $120-129 \mathrm{~mm} \mathrm{Hg}$ & and & $<80 \mathrm{~mm} \mathrm{Hg}$ \\
\hline \multicolumn{4}{|l|}{ Hypertension } \\
\hline Stage 1 & $130-139 \mathrm{~mm} \mathrm{Hg}$ & or & $80-89 \mathrm{~mm} \mathrm{Hg}$ \\
\hline Stage 2 & $2140 \mathrm{~mm} \mathrm{Hg}$ & or & $290 \mathrm{~mm} \mathrm{Hg}$ \\
\hline \multicolumn{4}{|c|}{$\begin{array}{l}\text { 'Individuals with SBP and DBP in } 2 \text { categories should be } \\
\text { designated to the higher BP category. } \\
\text { BP indicates blood pressure (based on an average of } \geq 2 \\
\text { careful readings obtained on } \geq 2 \text { occasions, as detailed in } \\
\text { Section } 4 \text { ); DBP, diastolic blood pressure; and SBP systolic } \\
\text { blood pressure. }\end{array}$} \\
\hline
\end{tabular}


Table 2. Classification of office blood pressurea and definitions of hypertension grade ${ }^{\mathbf{b}}$.

\begin{tabular}{llll}
\hline Category & \multicolumn{2}{c}{ Systolic $(\mathbf{m m H g})$} & Diastolic $(\mathbf{m m H g})$ \\
\hline Optimal & $<120$ & and & $<80$ \\
\hline Normal & $120-129$ & and/or & $80-84$ \\
\hline High normal & $130-139$ & and/or & $85-89$ \\
\hline Grade 1 hypertension & $140-159$ & and/or & $90-99$ \\
\hline Grade 2 hypertension & $160-179$ & and/or & $100-109$ \\
\hline Grade 3 hypertension & $\geq 180$ & and/or & $\geq 110$ \\
\hline Isolated systolic hypertension & $\geq 140$ & and & $<90$
\end{tabular}

$\mathrm{BP}=$ blood pressure; $\mathrm{SBP}=$ systolic blood pressure.

a BP category is defined according to seated clinic BP and by the highest level of BP, whether systolic or diastolic.

b Isolated systolic hypertension is graded 1, 2, or 3 according to SBP values in the ranges indicated.

The same classification is used for all ages from 16 years.

Source: Williams et al. [1]

The Department of Arterial Hypertension of the Brazilian Society of Cardiology (DHA-SBC) reevaluated the $7^{\text {th }}$ guideline, of 2016, in which normotensive patients would only be patients with values $\leq 120 \times 80 \mathrm{mmHg}$ [7]. In an addendum published in 2020, the reference for normotensive individuals became BP values $\leq 129 \times 84 \mathrm{mmHg}$. Between $130 \times 85$ and 139x89 mmHg, the patient would be pre-hypertensive and should be monitored and lifestyle changes instituted. Stage I of SAH, when values were constant between 140x90 and 159x99 mmHg, as well as in the european guideline [2] (table 3).

Table 3. Blood pressure classification according to the measurement in 18-year-old.

\begin{tabular}{lccc}
\hline Chart 3.4 - Classification of blood pressure from in-office measurement, ages 18 and up. & & DBP (mm Hg) \\
\hline Classification* & $\mathrm{SBP}(\mathrm{mm} \mathrm{Hg})$ & $<0$ \\
\hline Optimum BP & $<120$ & and & $80-84$ \\
\hline Normal BP & $120-129$ & and/or & $85-89$ \\
\hline Prehypertension & $130-139$ & andior & $90-99$ \\
\hline Stage 1 HT & $140-159$ & andior & $100-109$ \\
\hline Stage 2 HT & $160-179$ & andior & $\geq 110$ \\
\hline Stage 3 HT & $\geq 180$ & andior & \\
\hline
\end{tabular}

BP: blood pressure; DBP: diastolic blood pressure; HT: hypertension; SBP: systolic blood pressure. "Classification follows office BP and the highest BP level, either systolic or diastolic. " Isolated systolic HT, characterized by SBP $\geq 140 \mathrm{~mm} \mathrm{Hg}$ and DBP $<90 \mathrm{~mm} \mathrm{Hg}$, is classified as 1,2 or 3, according to SBP values at the intervals indicated. "' Isolated diastolic HT, characterized by $S B P<140 \mathrm{~mm} \mathrm{Hg}$ and DBP $\geq 90 \mathrm{~mm} \mathrm{Hg}$, is classified as 1,2 or 3, according to SBP values at the intervals indicated. 
The therapeutic approach to SAH is based on medicated and non-medicated treatments. Attention to hypertensive patients is important and must be done jointly involving family members, caregivers and health professionals. Actions implemented jointly have a positive impact on treatment adherence. Everyone involved has the role of educators and takes the lead in promoting health and preventing risks and diseases. The incentive should be given both in relation to adherence to drug treatment, as well as in encouraging changes in lifestyle [8].

Currently, another extremely important factor is related to the SARS-CoV-2 pandemic. Patients with SAH need to be extra careful. Health professionals as well as the family members, must be aware. These patients are considered to be at high risk if they contract the virus. The SARS-CoV-2 pandemic is characterized by the overproduction of inflammatory cytokines (IL-6 and TNF-a) leading to systemic inflammation and the multiple organ dysfunction syndrome affecting acutely the cardiovascular system. The SAH is the most prevalent comorbidity (56\%) among patients with COVID19 who need hospitalization [9].

In this context, hypertensive patients should avoid exposure to the virus, should not self-medicate, and medical care should be prompt, if they have symptoms of this viral infection [10].

\section{Effect of the white coat, white coat hypertension, masked hypertension and sustained hypertension}

The effect of the white coat (WCE) can affect both, normotensive and controlled hypertensive patients, being defined as a BP difference between the measurements obtained in the office and outside. Based on studies of HBPM (home blood pressure monitoring), differences $\geq 15 \mathrm{mmHg}$ in systolic pressure (SBP) and / or $\geq 9 \mathrm{mmHg}$ diastolic pressure (DBP) in the office, indicate WCE. This situation does not change the diagnosis, that should be based on the HBPM. When distrusting WCE, the patient should be better evaluated to identify the risk for relevant differences in BP, inside and outside the office, contributing to better therapeutic management. Several pressure phenotypes may be present in patients. True normotension is when BP measurements in the office and outside are "normal". Sustained hypertension (SH) occurs when both, systolic and diastolic pressure, are high inside and outside the office. White coat hypertension $(\mathrm{WCH})$ is due to WCE, while at masked hypertension (MH) is normal in the office and elevated outside [2].

\section{Blood pressure control in dental treatment}

An alert should be given to oral health professionals during their training about the correct and constant measurement of pressure values in their care. Dentistry is associated with anxiety, fear, stress and pain, and these factors are triggers for high BP, in hypertensive and normotensive patients [11].

Stress is the physiological response to situations that the central nervous system understands as aggression, as is the case with dental treatment. During stress, cortisol is released, systolic BP increases with consequent hemodynamic/ cardiovascular reactions [12]. There may also be a 40 -fold increased in the concentration of endogenous adrenaline, significantly increasing the basal levels of this hormone [13].

Usually, changes in physiological responses in the dental clinic, are not associated with the use of vasoconstrictors present in local anesthetics, but with fear and anxiety. Fear can be assessed by observing variations in BP and heart rate as soon as the patient arrives at the dental office [11]. The stress level is linked to the negative psychological perception of the treatment and not due to the difficulty involved in it [14].

Several cases of lipothymia, syncope, shock and even death have been reported during short dental procedures. Monitoring vital signs even during simple procedures, both in healthy patients but especially in those with systematic commitment, will assist professionals in preventing acute medical emergencies and in deciding on their resolution [15].

Measuring BP is a mandatory conduct for every health professional [2] who must be attentive to possible pressure changes before, during, at the end of the service and in the patient's discharge, aiming at the prevention of risks [4]. 
For outpatient care, such as elective dental procedures, the ideal blood pressure values for the start of the procedure should be $\leq 140 \times 90 \mathrm{mmHg}$ [13], and should be measured again during the clinical procedure, particularly in those patients with poor blood pressure control, as there are no guarantees that BP will remain at the initial levels, even in normotensive individuals [4].

Elective procedures but few invasive, such as small periodontal scaling, re-opening of implants, restorative dentistry and small tissue manipulations, can be performed with values of up to $160 \times 100 \mathrm{mmHg}$ as long as the patient is asymptomatic. In these cases in addition to the cardiologist's approval, which is mandatory, are recommended [13]:

1. short sessions

2. mild sedation with benzodiazepines or nitrous oxide / oxygen

3. promote aspiration before the injection of local anesthetic, thus avoiding intravascular injection

4. avoid bolus injection

5. use limited volumes of anesthetic solution and with the lowest possible concentrations of epinephrine $(1: 100,000$ or $1: 200,000)$

In dental emergencies, in which pain may be the cause of increased BP, clinical intervention is necessary but BP must be at levels bordering 180×110 mmHg. The sessions should be quick and focused only on pain relief. In such cases, it is important to opt for minimal preoperative sedation and an anesthetic solution based on prilocaine with felipressin at $0.03 \mathrm{IU} / \mathrm{ml}$ (limit of 2-3 cartridges). As far as possible, the monitoring of vital signs should be continuous and the practice of iatrosedation should be maintained. If the values are greater than $180 \times 110 \mathrm{mmHg}$, the urgency must be met in a hospital environment. Elective care of any kind is not recommended with these levels [13].

The maximum anesthetic dose calculation are made according to the anesthetic salt and the patient's body weight. However, in those who are undergoing treatment for hypertension and who are not yet effectively controlled, these calculations should be reevaluated. In these cases, the anesthetic dose should not be based only on the anesthetic salt (ex: lidocaine $-4.4 \mathrm{mg} / \mathrm{kg}$, at the limit of 300mg per session), but also on the vasoconstrictor. For epinephrine, the maximum dose recommended by the FDA (Food and Drug Administration) for hypertensive patients is $0.04 \mathrm{mg}$ (or 40 $\mu \mathrm{g})$ per session, which means that for a solution with epinephrine in a concentration of 1:100,000 (18 $\mu \mathrm{g})$, the maximum volume would be two anesthetic cartridges and for the concentration of 1:200,000 (9 $\mu \mathrm{g})$, the limit would be four cartridges [16].

Many doctors are unaware that the anesthetic cartridge used in dentistry are $1.8 \mathrm{ml}$ and contain small amounts of vasoconstrictor, usually $1: 100,000$ or 1:200,000 epinephrine, or 1:50,000 norepinephrine (36 $\mu \mathrm{g} /$ cartridge). This lack of knowledge leads these professionals, mainly cardiologists, to contraindicate anesthetics with vasoconstrictors, guiding the use of local anesthetics without vasoconstrictors. They are also unaware that there are other vasoconstrictors besides those mentioned, such as felipressin (in Brazil, only in the concentration of $0.03 \mathrm{IU} / \mathrm{mL}$ ), corbadrine at 1:20,000 and phenylephrine at 1:2,500 [13].

This contraindication may result from the use of much higher concentrations of epinephrine by doctors. In fact, and in emergencies (acute asthma attack, anaphylactic shock and cardiac arrest), these professionals use an epinephrine ampoule with $1 \mathrm{mg} / \mathrm{mL}$, that is, 1:1,000. The dose of epinephrine recommended by the FDA during anaphylactic shock in adults and children over $30 \mathrm{~kg}$ is $0.3 \mathrm{mg}(300 \mu \mathrm{g})$ at $0.5 \mathrm{mg}(500 \mu \mathrm{g})$ by application. In that case, these doses can be repeated, if necessary, after 5 to 10 minutes. In pediatric, elderly or extremely thin patients, the total dose is $0.01 \mathrm{mg} / \mathrm{kg}$, with a limit of $0.3 \mathrm{mg}$ subcutaneously or intramuscularly (IM). Venous infusion is indicated in patients with arterial hypotension, signs of shock or in those who do not respond to IM administration of epinephrine and volume replacement. The dose is $0.05 \mathrm{mcg} / \mathrm{kg} / \mathrm{min}$ to $2 \mathrm{mcg} / \mathrm{kg} / \mathrm{min}$, titrated to achieve the desired mean arterial pressure $[17,18]$.

These doses are not used to establish the dosage limit for local anesthetics with vasoconstrictors in dental patients [4]. 
As the dental surgeon works on an outpatient basis, with the patient most of the time awake and completely lucid, the stress situation added to the pain caused by the inefficiency of the anesthetic without vasoconstrictor, can cause a increased by 40 -fold endogenous adrenaline discharge. Adrenergic levels can reach $280 \mu \mathrm{g} / \mathrm{min}$ and this is much more harmful than the use of anesthetic cartridge with only $18 \mu \mathrm{g}$ of vasoconstrictor [13].

\section{Correct BP measurement}

During BP measurement, the surgeon must observe some precautions. The patient must remain at rest for at least 5 minutes before the measurement, must not have exercised or eaten in the last hour and must not have had coffee or alcohol in the last 30 minutes, as these factors are known to increase BP. The patient should sit with his legs parallel to each other. The feet, back and arms must be supported and there should be no conversation during the measurement. The measured arm should be slightly stretched, between 450 and 900 in relation to the long axis of the body and supported with the palm facing upwards. The measurement must be carried out at least 3 times for conference with intervals of 1 to 3 minutes between them. Measuring devices must be calibrated regularly, the sphygmomanometer cuff must be of an appropriate size for each patient's arm thickness and age, always positioned 2 to $3 \mathrm{~cm}$ above the cubital fossa centered on the brachial artery. The diaphragm of the stethoscope must rest on the brachial artery in the cubital fossa below the cuff, never under it [7].

It is important to note that the BP measurement can be influenced by the type of equipment used. Although the mercury column sphygmomanometer is considered the gold standard for indirect BP measurement, there are recommendations on its removal due to the potential for environmental contamination. As the auscultatory technique remains the reference for indirect measurement, aneroid sphygmomanometers can be chosen. Digital oscillometric dispositives, of wrist or arm, can also be used. The American Heart Association considers that is possible to perform measurements on the forearm, however, points out that they are not applied due to the possibility of obtaining high, false values, characterizing non-true hypertension. The measurement on the wrist may overestimate the measurements due to the differences between the diameters of the brachial and radial arteries, which is thinner [19]. Whatever the choice of equipment by the professional, it is necessary to consider the need for periodic calibration. Whenever possible, it is recommended to use the same equipment on the same patient to control different values.

Smoking patients, frequent users of caffeine, patients being treated with various types of medication, particularly prolonged use of non-steroidal anti-inflammatory drugs (NSAIDs), may have their BP altered and should not be immediately classified as hypertensive [4].

Caffeine can increase blood pressure acutely for more than three hours but regular consumption in low doses leads to tolerance. Smoking has considerable potential to cause harm, accelerating atherothrombotic processes with temporary BP elevation. Tobacco use can raise BP around 5 to $10 \mathrm{mmHg}$, on average [2].

The NSAIDs are inhibitors of cyclooxygenase responsible for the synthesis of prostaglandins (PG) that act in the renal parenchyma maintaining renal perfusion, volume regulation, sodium and water excretion. Among the PGs is prostacyclin, which secreted by endothelial cells, is responsible for relaxing smooth muscles with a vasodilatory effect. The chronic use of NSAIDs impaired both renal function and the vasodilator effect, increasing BP. In addition, there is a probable interference of NSAIDs with antihypertensive drugs due to antagonistic effects [20].

In the elderly, diabetics, dysautonomics or in those using antihypertensive drugs, BP should also be measured while standing. The measurement must be after 1 minute standing and 3 minutes (still). Orthostatic hypotension is defined as a reduction in SBP $\geq 20 \mathrm{mmHg}$ or DBP $\geq 10 \mathrm{mmHg}$ within the 3rd minute and is associated with an increased risk of mortality and cardiovascular events [2].

It is important to guide the emptying of the bladder before measuring $\mathrm{BP}$, in addition to keeping the patient comfortable in relation to the ambient temperature[4]. The urine accumulated for 3 hours, counted since the last urination, influences the diastolic BP in increments of $10 \mathrm{mmHg}$ and systolic pressure in more than $7 \mathrm{mmHg}$ [21]. 
The very low ambient temperature can activate the sympathetic system by increasing the BP, keeping it higher for a longer period [22]. There are reports of increases of 10 to $30 \mathrm{mmHg}$ after exposure to cold and in some cases up to $60 \mathrm{mmHg}$ [23]. In the face of these changes, comfort and control measures must be taken, such as warming the patient to reduce cardiac stress [24].

Some digital devices indicate positioning on the left arm, but there is no universally accepted indication of the best arm to use. It would be extremely prudent that, in a first assessment, the PA was measured in both arms. This is very important in hypertensive patients and/or over the age of 50 . The reference would be the arm with the highest pressure value, both in medical/dental procedures and for the hypertension treatment control. Unfortunately, many health professionals do not adopt this conduct [5].

\section{Difference in blood pressure between arms}

Patients with advanced age, smoking, hypertension, diabetes and hypercholesterolemia are strong candidates for the atheromatous plaques formation in important arteries [25].

Chronic degenerative diseases, characterized by the obstruction of blood vessels by cholesterol plaques (atheromas), contribute to a lower blood pressure in the ipsilateral arm of the arteries involved. The diagnosis can be made in routine appointment when the differences in BP between the arms will be associated with a significant increase in cardiovascular risks [26].

Many professionals are aware of the difference in BP value between arms, but few are aware of the extent of this difference and the risks involved [27].

Differences $>10 \mathrm{mmHg}$ in SBP between arms have already been observed in about $20 \%$ of patients, $8.1 \%$ had diferences $>10 \mathrm{mmHg}$ in DBP and only $4.2 \%$ had a difference in SBP $>20 \mathrm{mmHg}$ [28]. Another study showed that $23 \%$ of patients had differences in SBP $>10 \mathrm{mmHg}, 6 \%$ with differences in DBP $>10 \mathrm{mmHg}$ and only $3 \%$ with difference in SBP $>20 \mathrm{mmHg}$ [29]. These studies [28,29], as well as others [30,31] warn about the increased risks of cardiovascular events when the differences in systolic BP are $\geq 10 \mathrm{mmHg}$ between arms, and preventive control measures must be established.

Patients with differences in systolic pressure $\geq 10 \mathrm{mmHg}$ between arms should undergo cardiovascular assessments. Differences $\geq 15 \mathrm{mmHg}$ are very indicative of the vascular disease presence, such as subclavian stenosis with significant risk of death [32].

There is an intimate association of the BP difference between arms and intra and extracranial arterial stenoses, with a higher risk of ischemic stroke. Atheromas can exist not only in the arteries that will irrigate the upper limbs, but also in other arteries such as the vertebral and common carotid arteries [33].

The dental surgeon is able to make this type of diagnosis and, if positive, refer the patient for treatment. A female patient, 75 years old, with altered cholesterol, controlled hypertension with antihypertensive drugs. The preoperative exams and cardiac evaluation were made and she was released for dental surgical procedures (grafts and oral implant). In the first surgery, BP was measured on the left arm, in the preoperative, according to the clinic protocol, presenting the values of 130x80 $\mathrm{mmHg}$. No complications in the trans or postoperative period. In the second surgery, 7 months later, preoperative BP was also measured $(130 \times 90 \mathrm{mmHg})$ in the left arm, with no changes in the trans and postoperative periods. Thirty days after the second surgery, a third surgery, pre-operative BP was high $(210 \times 130 \mathrm{mmHg})$ during several measurements and with different equipment. The difference noted in that session was due the measurement in the right arm, randomly chosen by the dental surgeon, using an aneroid sphygmomanometer and stethoscope. The BP was then measured on the left arm and, as in all previous surgeries, it had a pressure of $130 \times 90 \mathrm{mmHg}$. The procedure was canceled, as the difference between arms was $80 \mathrm{mmHg}$ in the systolic and $40 \mathrm{mmHg}$ in the diastolic. The patient, even asymptomatic, was immediately referred to the emergency department with the clinical report and diagnostic hypothesis, given by the dentists team, of stenosis in the left subclavian artery. After appointments with the cardiologist and vascular 
surgeon, this diagnosis was confirmed and the total stenosis at the subclavian artery origin, was reduced with angioplasty and the installation of a stent. The medical diagnosis also included stenosis of $70 \%$ of the ipsilateral vertebral artery, with an increased risk of stroke, with the consequent prescription of antiplatelet agents and new antihypertensives. Due to the isolated systolic hypertension, similar in both arms $(185 \times 83 \mathrm{mmHg}$ on the right and $182 \times 80 \mathrm{mmHg}$ on the left) even after treatment, the patient was referred for a less invasive dental procedure [5]. This case is important to emphasize the importance of analyzing and associating all signs and symptoms, before any decision is made [4,34].

Important to remember that, even with a cardiac evaluation prior to surgery, this serious problem was not initially diagnosed by the medical team [5].

Subclavian artery stenosis is closely associated with subclinical heart disease [26].

There may also be, although rare, stenosis of the brachio-encephalic trunk. This is located on the right side and contemplates, in addition to the right subclavian artery, the right common carotid artery. With the stenosis of the trunk, in addition to the pressure difference between the arms and the decrease in heart rate in the right wrist, lipothymia can occur due to the interruption or inversion of the right carotid artery flow [35].

Neglecting to measure BP in both arms can result in a false sense of security. For patients over 50 years old, hypertensive, diabetic, smokers or with lipid dysfunction, it is recommended to measure BP in both arms, by any health professional, at least once a year. Unfortunately, this is an uncommon practice even in the medical field, being mandatory to consider the highest pressure value when drawing up a treatment plan. The patient should be referred for a more detailed cardiological evaluation if the difference in BP values between the arms is $\geq 10 \mathrm{mmHg}$ [5].

\section{Isolated systolic hypertension}

With the aging and stiffening of the aortic artery, a different clinical condition of SAH can set in. It is called isolated systolic hypertension (ISH) when the systolic pressure is greater than $140 \mathrm{mmHg}$ and the diastolic pressure remains $\leq 90 \mathrm{mmHg}$. This condition can be caused by salt excess in the diet and a consequent imbalance in the renin-angiotensin-aldosterone system [36].

The case reported above in the 75-year-old patient is a classic ISH condition. Although controlled with combination therapies, SBP was higher than the ideal values for invasive dental treatment [5].

The ISH is quite common in the elderly and is associated with uncontrolled SAH from the fifth decade of life or with salt excess in the diet. In ISH, cardiovascular risk is high and is the result of less complacency of large vessels in the elderly, a phenomenon that was once understood as a "normal" consequence of aging. Achieving ideal systolic pressure values without adverse effects is a difficult task in clinical practice. There is evidence that modulation of the renin-angiotensin system brings additional benefits, especially for patients at high cardiovascular risk. The therapeutic regimen with angiotensin receptor blockers associated with low dose thiazide diuretics is an excellent choice for elderly individuals with ISH [37].

\section{Hypertensive crisis}

The severe, extreme and sudden BP increase in adults, with values $\geq 180 \times 120 \mathrm{mmHg}$, is called a hypertensive crisis (HC) [38]. Generally, a diastolic value $\geq 120 \mathrm{mmHg}$ is the most appropriate indicator in this classification [39].

Some patients, even with systolic values greater than $180 \mathrm{mmHg}$ but the diastolic value still at $110 \mathrm{mmHg}$, are already considered as a clinical condition of HC, depending on the associated symptoms [40].

The HC can occur in controlled or uncontrolled hypertensive individuals, in those who do not strictly follow the treatment recommended by the doctor, but also in normotensive individuals, and the crisis is considered dangerous regardless of the patient [41]. 
The sudden increase in BP characterizing $\mathrm{HC}$ has subdivisions. It is called hypertensive urgency (HU) when the increase in BP is accompanied by mild symptoms (headache, dizziness, tinnitus), but without target organ injury (TOI). In these cases, the patient must be referred to the health system with a companion for detailed examinations to be performed. Faced with severe symptoms (dyspnoea, chest pain, speech difficulties, acute occipital headache, blurred vision, severe nosebleed or loss of movement), the patient should be taken by an emergency medical service and immediately transferred to the hospital, as there may be TOI and risk of death. This is the description of a classic condition called hypertensive emergency (HE), which is definitely diagnosed only with laboratory and eye fundus exams [42].

The HU should be treated only by doctors, in order to promote a gradual reduction in BP with oral antihypertensives [38], usually captopril (angiotensin-converting-enzyme inhibitor) followed or not by clonidine (alpha-2 adrenergic agonists), within 24 to 72 hours and starting in a hospital as the abrupt and intense reduction in BP, can cause renal, cerebral and coronary ischemia [43]. The patient can only be discharged when the BP is $\leq 180 \times 110 \mathrm{mmHg}$, as long as asymptomatic $[7,44]$.

The EH can cause irreversible damage to the brain, heart and kidneys, and requires immediate reduction in blood pressure levels, which should only occur in a hospital environment. The chosen drugs are administered intravenously, together with other supportive measures, avoiding the high risks of acute myocardial infarction, stroke and dissection of important vessels such as the aorta artery $[7,38,44]$.

Worldwide, there were 17 million deaths / year from cardiovascular diseases and 55\% of them, or almost 10 million, are associated with hypertensive crises [45].

$\mathrm{UH}$ and EH should be differentiated from hypertensive pseudo-crisis (HPC), which is characterized by a marked but transient increase in BP, in the face of emotional stimuli such as anxiety, fear, stress, panic syndrome, rotational dizziness or painful events, such as severe headache [46]. Requires only symptomatic treatment, usually with anxiolytics and / or analgesics [38].

Um study with 100 patients admitted to the emergency department with HPC, observed the evolution of blood pressure after the administration of dipyrone associated with diazepam in 50\% of them and only captopril in the others. Both protocols resulted in a satisfactory and similar drop in BP. It was concluded that analgesic / anxiolytic treatment with approach and control of causes, may be sufficient to reduce BP in cases of HPC [44].

In the case of HCP, it is important to identify the cause and if it is associated with fear and anxiety, it must be controlled first with latrosedation (frank and serene dialogue between professional and patient), being very positive and recommended [4]. Sedation with anxiolytics and analgesics can be used and is generally more effective [47].

Alprazolam, used as an anxiolytic at doses of 0.25 to $0.5 \mathrm{mg}$, has been shown to be safe, especially in the elderly. Plasma half-life is shorter than diazepam, with a lower incidence of adverse effects when compared to midazolam [13]. In addition, the alprazolam has been shown to be as effective as captopril in reducing BP in emergency services [48]. Minimal sedation with alprazolam has already been associated with a reduced risk of serious cardiovascular events, such as hemorrhagic stroke and acute myocardial infarction, particularly in the elderly [49].

It is important to note that high BP values alone do not characterize emergency, urgency or pseudo-crisis. The case previously reported about the 75-year-old patient showed that, although the patient had a BP of $210 \times 130 \mathrm{mmHg}$, the patient was totally asymptomatic [5].

Thus, in order to define a $\mathrm{HC}$, in addition to the absolute pressure value, the symptoms and the speed of the BP values elevation, must be evaluated $[2,4,7]$.

There are almost 10 million deaths worldwide due to the sudden increase in BP, 51\% of which are attributed to stroke and $45 \%$ to cardiac ischemia [45].

An imbalance between vascular resistance and cardiac output causes a sudden increase in BP, overloading blood vessels and the heart. Overload can cause damage to the vascular endothelium and necrosis of arterioles. As a response, there is deposition of platelets and fibrin, causing reduction of the lumen, increasing the resistance of the vascular walls and hindering the contraction/dilation necessary to control blood flow. Ischemia or hypovolemia caused by irregular 
blood supply stimulates the release of vasoactive substances, generating a vicious circle of vasoconstriction and increased BP [50].

A cross-sectional and retrospective study was carried out in an emergency department to identify patients with HC. There were 435 adults (aged over 18 years) who met the inclusion criteria such as diastolic BP $\geq 120 \mathrm{mmHg}$. The vast majority of crises were classified as HU (312) followed by HE (83) and HPC (40). The main symptoms of HE were dyspnea and neurological disorders; in the HU there were headache and malaise; the triggers for HPC were anxiety and pain [38].

It is important to note that during episodes of pain, which is already considered the fifth vital sign, there is a decompensation of other vital signs such as breathing, heart rate and BP [51].

There is little data regarding $\mathrm{HC}$ in dental services in Brazil. One study showed that this clinical condition was the fourth most common occurrence reported by professionals, representing $15 \%$ of emergencies in dental offices [52].

A study showed that during a procedure for oral implant installations, a male 64 years old, although he underwent cardiac evaluation in the preoperative period and, according to the brazilian guidelines of hypertension and with clinical exams performed, he was classified as normotensive $(126 \times 84 \mathrm{mmHg})$, he evolved during the operation to a HC. The BP values close to "normal" were maintained in pre-operative measurements, however, on the day of surgery, the patient had a BP of $160 \times 100 \mathrm{mmHg}$, characterized at that time as white coat hypertension. The patient was then medicated with $0.25 \mathrm{mg}$ of alprazolam and after 1 hour, the BP was $130 \times 80 \mathrm{mmHg}$. The surgery started, but 90 minutes later, the patient was agitated, with cold, profuse bleeding at the surgery site, cold skin and reporting the need to empty his bladder. The BP was measured at $228 \times 134 \mathrm{mmHg}$ and the surgery was immediately canceled. The temperature in the room was increased, it was $17^{\circ} \mathrm{C}$ and the air conditioner was turned off, also iatrosedation was instituted. The patient was followed to the bathroom and after that, received $500 \mathrm{mg}$ of analgesic for pain control at the surgery site. Five minutes after these measures, the BP decreased to $201 \times 123 \mathrm{mmHg}$. Monitored every 20 minutes, BP gradually decreased to $170 \times 120$ $\mathrm{mmHg}, 170 \times 100 \mathrm{mmHg}, 160 \times 100 \mathrm{mmHg}$ and finally to $140 \times 90 \mathrm{mmHg}$. Asymptomatic, the patient was discharged with a companion and, after $24 \mathrm{~h}$, BP was measured $(127 \times 81 \mathrm{mmHg})$. The authors concluded that it was a classic case of HPC. Although frightening, the immediate reduction in blood pressure levels through the administration of antihypertensive drugs was not indicated, as a sudden drop in BP could cause a true hypotensive crisis, much more worrying than the HPC [4].

In fact, the sudden reduction in BP can lead to cerebral or myocardial infarction, transforming pseudocrisis into a true death-threatening emergency $[4,43,50]$. Thus, in dental offices, the administration of antihypertensive drugs is not indicated, as already shown in the specialized literature.

Emergencies in dental offices related to changes in blood pressure or lipothymia, appear more frequently during or shortly after the local anesthetics infiltration or during surgical procedures. Anxiety, fear and pain must be previously controlled to avoid sudden increases in BP and risks of cardiovascular complications, especially in the elderly $[16,53]$.

Blood pressure control is very important even in young and / or normotensive patients. It is always necessary to consider that not only old people have $\mathrm{HC}$ and that numerical values not classify a hypertensive crisis, but the set of signs and symptoms already described $[4,41]$.

Regarding control also in young and / or normotensive patients, a prospective study, looking at individuals with $\mathrm{HC}$ in an emergency unit, found that the majority of patients were men, young people, smokers and with regular alcohol consumption. In this study, 30\% of those evaluated did not have a previous history of SAH [54].

So, the approach of patients must occur during any care and, particularly for the most symptomatic patients, this care must be multidisciplinary, involving doctors, nurses, nutritionists, occupational therapists, physical educators and psychologists, in addition to dentists [55]. 


\section{CONCLUSION}

Health professionals are responsible for the prevention and control of medical emergencies in dental offices.

The care for patients over 50 years of age, whether hypertensive or not, with hypercholesterolemia, diabetes and anxiety should involve monitoring vital signs, as well as the pain score.

The measurement of blood pressure should happen at the first office visit, in both arms, and repeated at least once every year.

In all procedures, blood pressure control, as well as the assessment of all vital signs, must take place before, during, after the procedure and before discharge, especially when the use of local anesthesia is significant.

In the face of any major change in vital signs, the risk / benefit ratio of continuing the procedure should be assessed to avoid or minimize greater risks to patients.

The learning curve increases, the risks decrease, but they will never be null.

Collaborators

MC Pedrazini, researcher responsible for the conceptualization, bibliographic review, writing and article submission. LFG Odone, researcher responsible for technical informations in medical bibliography reviews. MF Groppo, researcher responsible to suppport in the final text reviews - technical informations. FC Groppo, researcher responsible for support in writing and final article review.

\section{REFERENCES}

1. Williams B, Mancia G, Spiering W, Rosei EA, Azizi M, Burnier $M$, et al. ESC / ESH Guidelines for the management of arterial hypertension: The Task Force for the management of arterial hypertension of the European Society of Cardiology (ESC) and the European Society of Hypertension (ESH). Eur Heart J. 2018;39(33):3021-3104. https://doi.org/10.1093/eurheartj/ ehy339

2. Barroso WKS, Rodrigues CIS, Bortolotto LA, Gomes MAM, Brandão AA, Feitosa ADM, et al. Brazilian Guidelines on Arterial Hypertension - 2020. Arq Bras Cardiol. 2021 Mar;116(3):516658. https://doi.org/10.36660/abc.20201238

3. Brasil. Ministério da Saúde. One in four Brazilian adults say they have a medical diagnosis of hypertension [cited 2021 Fev 20]. Available from: <http://www.saude.gov.br/noticias/ agencia-saude/43123-um-em-cada-quatro-brasileirosadultos-dizem-ter-diagnostico-medico-de-hipertensao>.

4. Pedrazini MC, Groppo FC. Hypertensive crisis: considerations and conducts in the surgeries in Implantology. INPerio. 2020;5(2):260-7

5. Pedrazini MC, Montagner AM, Shimaoka CA, Held AB, Alves ALC. The significance of a high difference in blood pressure between the two arms and before dental implants: a worrying alert, reflections and treatment. INPerio. 2016;1(8):1561-9.

6. Whelton PK, Carey RM, Aronow WS, Casey IN, Collins KJ, Himmelfarb CD, et al. 2017 ACC / AHA / AAPA / ABC / ACPM / APhA / ASH / ASPC / NMA / PCNA guideline for the prevention, detection, evaluation, and management of high blood pressure in adults: a report of the American College of
Cardiology / American Heart Association Task Force on Clinical Practice Guidelines. J Am Coll Cardiol. 2018;71(19):e127-e248. https://doi.org/10.1161/HYP.0000000000000066

7. Malachias MVB, Souza WKSB, Plavnik FL, Rodrigues CIS, Brandão AA, Neves MFT, et al. Brazilian Society of Cardiology - SBC. VII Brazilian Guidelines on Hypertension. Arq Bras Cardiol. 2016;107(3):1-82. https://doi.org/10.5935/ abc.20160151-20160163

8. Gewehr DM, Bandeira VAC, Gelatti GT, Colet CF, Oliveira $\mathrm{KR}$. Adherence to the pharmacological treatment of arterial hypertension in Primary Health Care. Saúde Debate. 2018;42(116):179-190. https://doi.org/10.1590/01031104201811614

9. Azevedo RB, Botelho BG, Hollanda JVG, Ferreira $L V L$, Junqueira de Andrade LZ, Oei SSML, et al. Covid-19 and the cardiovascular system: a comprehensive review. J Hum Hypertens. 2021 Jan;35(1):4-11. https://doi.org/10.1038/ s41371-020-0387-4

10. Salazar M, Barochiner J, Espeche W, Ennis I. COVID-19, hypertension and cardiovascular disease [COVID-19 and its relationship with hypertension and cardiovascular disease]. Hypertension Riesgo Vasc. 2020; 37 (4): 176-180. doi: 10.1016/j.hipert.2020.06.003

11. Fernandez-Aguilar J, Guillén I, Sanz MT et al. Patient's pre-operative dental anxiety is related to diastolic blood pressure and the need for post-surgical analgesia. Sci Rep. 2020;10(9170):1-9. https://doi.org/10.1038/s41598-02066068-9 
12. Liau FL, Kok SH, Lee JJ, Kuo RC, Hwang CR, Yang PJ, et al. Cardiovascular influence of dental anxiety during local anesthesia for tooth extraction. Oral Surg Oral Med Oral Pathol Oral Radiol Endod. 2008;105:16-26. https://doi. org/10.1016/j.tripleo.2007.03.015

13. Andrade ED. Terapia medicamentosa em Odontologia. 3 ed. São Paulo: Artes Médicas; 2014.

14. Raocharernporn S, Boonsiriseth K, Khanijou M, Wongsirichat N. Hemodynamic changes and pain perception-related anxiety after experiencing an impacted-tooth removal: clinical practice outcome. J Dent Anesth Pain Med. 2017;17(2):105111. https://doi.org/10.17245/jdapm.2017.17.2.105

15. Gadve VR, Shenoi $R$, Vats $V$, Shrivastava A. Evaluation of anxiety, pain, and hemodynamic changes during surgical removal of lower third molar under local anesthesia. Ann Maxillofac Surg. 2018;8(2):247-253. https://doi.org/10.4103/ ams.ams_216_18

16. Malamed SF. Manual de anestesia local. $\sigma^{\text {a }}$ ed. Rio de Janeiro: Elsevier, 2013.

17. Highlights of prescribing information - adrenaline (epinephrine injection) $1 \mathrm{mg} / \mathrm{mL}$, for intramuscular, subcutaneous, and intravenous use. Stockbridge NL. Food and Drug Administration (FDA), 2019. Reference ID: 4382486. Medicine leaflet.

18. Panchal AR, Berg KM, Hirsch KG, Kudenchuk PJ, Del Rios M, Cabañas JG, et al. 2019 American Heart Association Focused Update on Advanced Cardiovascular Life Support: Use of Advanced Airways, Vasopressors, and Extracorporeal Cardiopulmonary Resuscitation During Cardiac Arrest: An Update to the American Heart Association Guidelines for Cardiopulmonary Resuscitation and Emergency Cardiovascular Care. Circulation. 2019;140:e881-e894. https://doi.org/10.1161/CIR.0000000000000732

19. Arcuri EAM, Rosa SCD, Scanavini RM, Denzin GSC. Blood pressure measurement in the arm and forearm as a function of the cuff. Acta Paul Enferm. 2009;22(1):37-42. https:// dx.doi.org/10.1590/S0103-21002009000100006

20. Khatchadourian ZD, Moreno-Hay I, Leeuw R. Nonsteroidal anti-inflammatory drugs and antihypertensives: how do they report? Oral Surg Oral Med Oral Pathol Oral Radiol. 2014 Jun;117(6):697-703. https://dx.doi.org/10.1016/j. 0000.2014 .02 .028

21. Choi EJ, Jeong DW, Lee JG, Lee S, Kim YJ, Yi YH, et al., The impact of bladder distension on blood pressure in middle aged women. Korean J Farm Med. 2011 Jul;32(5):306-10. https://dx.doi.org/10.4082/kjfm.2011.32.5.306

22. Kellogg DL Jr. In vivo mechanisms of cutaneous vasodilation and vasoconstriction in humans during termoregulatory challenges. J Appl Physiol. 2006;100(5):1709-18. https:// dx.doi.org/10.1152/japplphysiol.01071.2005

23. Hintsala $H$, Kandelberg A, Herzig $K H$, Rintamaki $H$, Mantysaari M, Rantala A, et al. Central aortic blood pressure of hypertensive men during short-term cold exposure. Am J Hypertens. 2014;27:656-64. https://dx.doi.org/10.1093/ajh/ hpt136

24. Hintsala $H$, Kiviniemi AM, Tulppo M, Helakari $H$, Rintamaki $H$, Mantysaari $M$, et al. Hypertension does not the increase in cardiac baroreflex sensitive caused by moderate cold exposure. Front Physiol. 2016 Jun;7(204):1-8. https://dx.doi. org/10.3389/fphys.2016.00204

25. Deşer SB, Yucel SM, Demirag MK, Kolbakir F, Keceligil HT. Relationship of inter-arm systolic blood pressure difference with subclavian artery stenosis and vertebral artery stenosis in patients undergoing carotid endarterectomy. Braz J Cardiovasc Surg. 2019;34(2):136-41. https://doi.org/10.21470/16789741-2018-0257

26. Clark CE, Aboyans V. Interarm blood pressure difference: more than an epiphenomenon. Nephrol Dial Transplant. 2015;30(5):695-97. https://dx.doi.org/10.1093/ndt/gfv075

27. Giles TD, Egan P. Inter - Arm difference in blood pressure may have serious research and clinical implications. J Clin Hypertens. 2012 Aug; 14 (8): 491-2. https://dx.doi. org/10.1111/j.1751-7176.2012.00668.x

28. Clark CE, Campbell JL. Evans PH, Millward A. Prevalence and clinical implications of the inter-arm blood pressure difference: a systematic review. J Human Hypertens. 2006;20:923-31. https://dx.doi.org/10.1038/sj.jhh.1002093

29. Clark CE, Campbell JL, Powell RJ. The interarm blood pressure difference as predictor of cardiovascular events in patients with hypertension in primary care: cohort study. J. Human Hypertens. 2007; 21: 633-38. https://dx.doi.org/10.1038/ sj.jhh.1002209

30. Weinberg I, Gona P, Murabito J. The systolic blood pressure difference between arms and cardiovascular disease in the Framingham Heart Study. Am J Med. 2014 Mar;127(3):209-15. https://dx.doi.org/10.1016/j.amjmed.2013.10.027

31. Yamamoto $T$, Miura SI, Suematsu $Y$, Kuwano $T$, Sugihara $M$, Ike $A$, et al. A relative difference in systolic blood pressure between arms by synchronal measurement and conventional cardiovascular risk factors are associated with the severiry of coronary atherosclerosis. Heart Vessels. 2016;31(6):863-70. https://dx.doi.org/10.1007/s00380-015-0683-z

32. Clark CE, Taylor RS, Shore AC, Ukoumunne OC, Campbell JL. Association of a difference in systolicblood pressure between arms with vascular desease and mortality: a systematic review and meta-analysis. Lancet. 2012;379(9819): 905-14. https:// dx.doi.org/10.1016/S0140-6736(11)61710-8

33. Wang $Y$, Zhang J, Qian $Y$, Tang $X$, Ling $H$, Chen $K$. et al. Association of inter-arm blood pressure difference with intracranial asyntomatic and extracranial arterial stenosis in hypertension patients. Sci Rep. 2016;6:29894. https://dx.doi. org/10.1038/srep29894

34. Silva IL, Martins E. Bilateral subclavian arterial stenosis: more than a drop in blood pressure - Case report. Rev Port Med Geral Fam. 2014;30(5):316-20.

35. Del Valle CE, Ferreira LFT, Bragato PH, Oliveira SL, Mauro FO, Araújo WJB. Total inversion of flow in the right internal carotid artery in a patient with severe stenosis of the brachiocephalic trunk. J Vasc Bras. 2020;19:e20190124. https://doi. org/10.1590/1677-5449.190124

36. Gonsalez SR, Ferrão FM, Souza AM, Lowe J, Morcillo LSL. Inappropriate activity of local renin-angiotensin-aldosterone system during high salt intake: impact on the cardio-renal 
axis. Braz J Bras Nefrol. 2018;40(2):170-178. https://doi. org/10.1590/2175-8239-jbn-3661

37. Almeida FA. Treatment of isolated systolic hypertension: the Val-Syst study. Rev Bras Hipertens. 2003;10(3):219-221.

38. Pierin AM, Flórido CF, Santos J. Hypertensive crisis: clinical characteristics of patients with urgency, emergency and hypertensive pseudocrisis in a public emergency service. Einstein (São Paulo). 2019;17(4):1-8. https://dx.doi. org/10.31744/einstein_journal/2019A04685

39. Ipek E, Oktay AA, Krim SR. Hypertensive crisis: an update on clinical approach and management. Curr Opin Cardiol. 2017;32(4):397-406. https://dx.doi.org/10.1097/ HCO.0000000000000398

40. Shao PJ, Sawe HR, Murray BL, Mfinanga JA, Mwafongo V, Runton MS. Profile of patients with hypertensive urgency and emergency presenting to an urban emergency department of a tertiary referral hospital in Tanzania. BMC Cardiovascular Disorders. 2018;18:158. https://dx.doi.org/10.1186/s12872018-0895-0

41. Franco RJS. Hypertensive crisis: definition, epidemiology and diagnostic approach. Rev Bras Hipertens. 2002;9:340-345.

42. Mandi DG, Yaméogo RA, Sebgo C, Bamouni J, Naibé DT, Kologo KJ et al. Hypertensive crises in sub-Saharan Africa: Clinical profile and short-term outcome in the medical emergencies department of a national referral hospital in Burkina Faso. Ann Cardiol Angeiol. 2019;68(4):269-274. https://dx.doi.org/10.1016/j.ancard.2019.07.007

43. Sobrinho S, Correia LCL, Cruz C, Santiago M, Paim AC, Meireles $B$, et al. Occurrence and clinical predictors of hypertensive pseudocrisis in emergency care. Arq Bras Cardiol. 2007;88(5):579-584. http://dx.doi.org/10.1590/ S0066-782X2007000500013

44. Lima SG, Nascimento LS, Santos Filho CN, Albuquerque MFPM, Victor EG. Systemic arterial hypertension in the emergency department. The use of symptomatic drugs as an alternative treatment. Arq. Bras. Cardiol 2005;85(2):115-123. http://dx.doi.org/10.1590/S0066-782X2005001500008

45. World Health Organization. Why hypertension is a major public health. A global brief on hypertension: silent killer, global public health crisis. World Health Day 2013. Geneva: WHO; 2013. Secction I: 8-9
46. Praxedes JN, Santello JL, Amodeo C, Giorgi DMA, Machado CA, Jabur P. Multicentre meeting on hypertensive crises: report and recommendations. Hypertension. 2001;4(1):23-41.

47. Silva MAM, Rivera IR, Santos ACS, Barbosa CF, Oliveira Filho CAS. Hypertensive crisis, hypertensive pseudocrisis and symptomatic elevation of blood pressure. Rev Bras Cardiol. 2013;26(5):329-36.

48. Yilmaz S, Pekdemir M, Tural U, Uygun M. Comparison of alprazolam versus captopril in high blood pressure: a randomized controlled trial. Blood Press. 2011;20(4):239-43. http://dx.doi.org/10.3109/08037051.2011.553934

49. Yeh CB, Tsai MC, Teng YH, Ku MS, Huang JY, Wang BY, Tai $\mathrm{CL}$, Kornelius E, Ho SW. Association of alprazolam with major cardiovascular events in patients with hypertension. J Eval Clin Pract. 2020;26(3):983-991. http://dx.doi.org/10.1111/ jep. 13254

50. Pegoraro JDL, Oliveira CA. Hypertensive crisis in Dentistry. RFO 2015; 20(3):380-383. http://dx.doi.org/10.5335/rfo. v20i3.4025

51. Thomas MA. Pain management - the challenge. Ochsner J. 2003;5(2):15-21.

52. Arsati F, Montalli VA, Flório FM, Ramacciato JC, Cunha FL, Cecanho R, et al. Brazilian dentists' attitudes about medical emergencies during dental treatment. J Dental Educ. 2010;74(6):661-666.

53. Feldstein C. Management of hypertensive crises. Am J Ther. 2007;14(2):135-9. http://dx.doi.org/10.1097/01. pap.0000249908.55361.de

54. Baumann BM, Abate NL, Cowan RM, Chansky ME, Rosa $\mathrm{K}$, Boudreaux ED. Characteristics and referral of emergency department patients with elevated blood pressure. Acad Emerg Med. 2007;14(9):779-84. doi: 10.1197/j.aem.2007.05.008

55. Pio-Abreu A, Drager LF. Blood pressure control: the secret is ... Team Work. Arq Bras Cardiol. 2020;115 (2):182-183. https:// doi.org/10.36660/abc.20200544 